\title{
Promising Impacts of Humic Acid and Some Organic Fertilizers on Yield, Fruit Quality and Leaf Mineral Content of Wonderful Pomegranate (Punica granatum $\mathbf{L}$.) Trees
}

\author{
Noha A.I. Mansour \\ Department of Horticulture, Faculty of Agriculture, Ain Shams University, Cairo, \\ Egypt.
}

\begin{abstract}
$\mathbf{T}$ HE AIMS of this research were to minimizing mineral nitrogen fertilizers and evaluate the efficiency of some organic fertilizers individually or combined with humic acid on yield, fruit quality and leaf mineral content of "Wonderful" pomegranate trees. This research was carried out through three successive seasons (2015, 2016 and 2017) in Hegazi private orchard located at 57 kilometer from Cairo on the desert road to Alexandria, Egypt on eight years old pomegranate trees "Wonderful" cv. The experiment consists of two levels of humic acid ( 0 and $50 \mathrm{~g} /$ tree/season) and five nitrogen fertilizers form [chicken manure, compost, cattle manure, mineral nitrogen as experiment control $40 \mathrm{~kg}$ actual $\mathrm{N} / \mathrm{fed}$ and mineral nitrogen as orchard control $80 \mathrm{~kg}$ actual $\mathrm{N} / \mathrm{fed}]$. The experiment was designed in factorial experiment in a randomized complete block design. All organic nitrogen sources applied at a rate of $40 \mathrm{~kg}$ actual $\mathrm{N} / \mathrm{fed}$. It could be concluded that, humic acid addition affected lack significant on yield, fruit physical and chemical properties and leaf nutrient content. Generally chicken manure and compost gave the highest values of most characters followed closely by two mineral treatments. When compared between two mineral $\mathrm{N}$ treatments the data revealed that $40 \mathrm{~kg} \mathrm{~N} / \mathrm{fed} /$ year was sufficient to give the highest values of most studied parameters and was equaled by $80 \mathrm{~kg} \mathrm{~N} / \mathrm{fed} /$ year. Regarding the combination between humic acid and nitrogen fertilizers the data showed that chicken manure and compost without addition of humic acid gave the highest values of yield and fruit characters followed closely by two mineral treatments. Thus it could be safely recommended by fertilizing with ( $40 \mathrm{~kg} \mathrm{~N} / \mathrm{fed} /$ year) instead of ( $80 \mathrm{~kg} \mathrm{~N} / \mathrm{fed} /$ year) on the other hand, fertilizing by chicken manure or compost ( $40 \mathrm{~g}$ $\mathrm{N} /$ tree/year) with or without humic addition $(50 \mathrm{~g} /$ tree/year $)$ improved yield ,fruit physical \& chemical properties and reduce environmental pollution.
\end{abstract}

Keywords: Chicken manure, Compost, Cattle manure, Fruit quality, Leaf mineral content, Mineral nitrogen, Wonderful pomegranate trees, Yield.

\section{Introduction}

The pomegranate (Punica granatum L.) was cultivated about 5000 years ago native to central Asia, following to the (Family: punicaceae). In Latin language pomegranate meaning "seeded apple". It is a small tree or shrub with fantastic spring red flowers( Lansky and Newman 2007). The fruit of the pomegranate, actually a berry, naturally divides into small bits of seed and pulp called "arils". Pomegranate are cultivated in tropical, sub-tropical and Mediterranean region since ages especially in Spain, Morocco, Egypt and the drier parts of California. Pomegranate species includes many cultivars such as Manfaloty, El hamede, Panaty, El sokry and Wonderful. Wonderful variety is well known in the world and it is one of the most cultivated species in California and usually used as a commercial juice with high potential health benefits. The fruit is red, big, with a bright appearance, its peel thickness is moderate, arils are small, red and present a good juice yield with high soluble solids content, high acidity (classified as sweet and sour variety) and a dark red color due to the high content of anthocyanins. For these characteristics, it is considered as a good variety for fresh market and also to be processed (Roy and Waskar, 1997).

Humic substances, such as organic matter, humus, humate, humic acid, fulvic acid and humin are play a main role in soil fertility and plant nutrition. Plants grown on soils which contain adequate humin, humic adds (HAs), and fulvic 
adds (FAs) are less subject to stress, healthy, gave high yield; and produced crops with high nutritional value. Humic acid (polymeric poly hydroxy acid) is the most important ingredient of organic substances in biological systems. Humic acid is high beneficial to plant and soil; it is play a significant role for increasing microbial activity. It is known as a plant growth bio-stimulate, it promotes nutrient uptake as chelating agent and improves vegetative characteristics and nutritional status (Eissa Fawzia et al., 2007 and Ismail et al., 2007). Humic acid is a complex compound derived from organic matter decomposition. Humic substances have indirect roles involve enhances of soil properties such as aggregation, permeability, aeration, water holding capacity, micronutrient transport and availability (Tan, 2003).

The old Egyptian growers knew an important deal about the value of certain material to plant growth, for they purposely applied both animal manure and ashes from burnt plants and weeds to the soil. The Egyptians had the great luck that their soil was continually renewed with alluvial deposits and flooded by regular inundation from the Nile (Lowrison, 1993). Nitrogen is one of the essential nutrients for plant nutrition; this fact was known in $19^{\text {th }}$ century. Nitrogen is added to plants through mineral and organic fertilization. However, part of mineral fertilizers used in crop production leaching to underground water causing disturbance in the biological balance and polluted underground water which in turn causes harmful effects for humans and animals (Postagate, 1978). Organic farming is a new technique for agriculture production to avoid chemical fertilizers addition. Eco-friendly effects on animal and human health encouraged farmers to convert to organic production (Fayed, 2005). Organic manure is derived from animal or plant residues. It is an excellent source of organic matter, macro- \& micro-nutrients, improves aeration, physical condition of soil, promotes root growth and production. It is a sound practice for sustainable agriculture base on low synthetically input. Integrated nutrient management is a production system which favors the maximum use of organic material and inhibits the use of chemical produced inputs for maintain soil productivity and fertility (Sudhakar et al., 2002). Compost application improved the soil chemical composition by increasing cation exchange capacity and soil nutrient content (Shiralipour et al., 1992). Chicken manure may be added as most available and economic alternate for compost to increase Superior grapevine yield, fruit quality and nutrients status as well as reducing pollution (Ahmed Abdelraheem et al., 2015).

Therefore, the targets of this study was to minimizing mineral nitrogen fertilizers and evaluate the efficiency of some organic fertilizers namely (chicken manure, compost and cattle manure) individually or combined with humic acid on the yield, fruit quality and leaf mineral content of Wonderful pomegranate trees

\section{Materials and Methods}

The experiment was carried out in three successive seasons (2016, 2017 and 2018) in Hegazi private orchard located at 57 kilometer from Cairo on the desert road to Alexandria, Egypt on eight years old pomegranate trees "Wonderful" cv., planted at $2 \times 5 \mathrm{~m}$ apart around (420 trees / Fed) grown under saran shading net and drip irrigation system was used. Forty uniform and healthy trees with no visual nutrient deficiency symptoms were selected and devoted for carrying out this experiment. The selected trees had the same agricultural treatments during three seasons of study. The orchard soil was sandy loam, the soil was analyzed according to Wilde et al. (1985). $\left(\mathrm{pH}=8.22, \mathrm{ECe}=8.0 \mathrm{dS} / \mathrm{m}, \mathrm{CaCO}_{3}=11.5 \%, \mathrm{~N}=\right.$ $108.6 \mathrm{ppm}, \mathrm{P}=26.3 \mathrm{ppm}$ and $\mathrm{K}=100.0 \mathrm{ppm}$ ),

Under this farm conditions nitrogen fertilizers were added at the rate of $80 \mathrm{~kg}$ actual N/fed (190.5 $\mathrm{g} \mathrm{N} /$ tree/season). The study consist of two levels of humic acid (0 and $50 \mathrm{~g} /$ tree/season) and five nitrogen fertilizers form, namely (chicken manure, compost, cattle manure, two mineral nitrogen treatments 40 and $80 \mathrm{~kg}$ actual N/fed Thus the experiment was laid out in factorial experiment in a randomized complete block design included ten treatments with four replicates and each replicate was represented by one tree.

Regarding humic treatments, the dose $50 \mathrm{~g} /$ tree/season ( $85 \%$ potassium humates) was added for selected trees around the dripper area in three equal doses at first week of March, May and July by dissolving humic dose in one liter of water. Control treatments (without humic acid) were irrigated with water.

Organic nitrogen from (chicken manure, compost and cattle manure, it was applied at $40 \mathrm{~kg}$ $\mathrm{N} /$ fed, each tree received (95.5 g N/tree/season). Mineral nitrogen treatments were added through drip irrigation system from different sources of common mineral nitrogen fertilizers like [calcium nitrate $(15.5 \%)$ ammonium sulfate $(20.5 \%)$ and ammonium nitrate (33.5\%)] according to 
the growth stage through the growing season, while organic nitrogen sources (chicken manure, compost and cattle manure) were added once in the second week of February in each season as a trench $(30 \mathrm{~cm}$ depth) under the drippers for each selected tree. All organic nitrogen sources obtained from the same place for each season, chemical analysis (average of three seasons) of the organic fertilizers was presented in Table 1.

\section{Measurements}

Chlorophyll content and leaf dry matter \%: Twenty fully expanded leaves 3 to 4 -month old from nonfruiting shoots at the middle third of the branch $5-7^{\text {th }}$ leaves from plant top were collected in mid-July to measure chlorophyll content and leaf dry matter. Chlorophyll content was measured by using a Soil Plant Analysis Division (SPAD) - 502 MINOLTA chlorophyll meter (Konica Minolta Business Solutions, Tokyo, Japan). Leaves were washed then weighted after air dried (fresh weight). Then leaves were oven dried at 60-70 till a constant weight (dry weight) and leaf dry matter $\%$ was calculated.

\section{Yield}

At maturity on the first week of October in each season the average number of fruits / tree was counted. Twenty fruit from each tree (replicate) were harvested to get the average fruit weight of each treatment. Such average was multiplied

TABLE 1. Characteristics of different organic fertilizers sources.

\begin{tabular}{lccc}
\hline Properties & Chicken manure & Compost & Cattle manure \\
\hline Weight of $\mathrm{m}^{3}(\mathrm{~kg})$ & 460.00 & 630.00 & 900.17 \\
Moisture content $(\%)$ & 24.30 & 35.60 & 22.84 \\
pH value $(1: 10)$ & 8.60 & 8.60 & 8.40 \\
EC value (1:10) (mmohs/cm) & 5.00 & 6.50 & 4.00 \\
Organic matter (\%) & 63.66 & 37.58 & 9.00 \\
Total nitrogen (\%) & 2.70 & 1.45 & 1.20 \\
C/N ratio & 11.89 & 13.38 & 3.80 \\
K (\%) & 0.87 & 1.23 & 0.90 \\
P $(\%)$ & 0.60 & 0.50 & 0.40 \\
\hline
\end{tabular}

by the average number of fruits / tree to get the average yield/tree $(\mathrm{kg})$.

\section{Fruit quality}

For each season, sample of six fruit / tree were randomly taken for the evaluation of physical and chemical fruit properties:

Peel thickness (mm), peel weight $(\mathrm{g})$, arils weight $(\mathrm{g})$, juice weight $(\mathrm{g})$, juice volume $(\mathrm{ml})$ were determined and estimated percentages of arils /fruit weight, juice/fruit weight and juice / arils weight were calculated.

The ascorbic acid content was determined by using 2, 6 dichlorophenolindophenol dye and $3 \%$ oxalic acid as substrate. Ascorbic acid was calculated as milligrams /100 milliliters of juice (AOAC 1995). Total acidity (TA) was determined by titrating $10 \mathrm{ml}$ of juice with $0.1 \mathrm{~mol} / \mathrm{L} \mathrm{NaOH}$ to $\mathrm{pH} 8.1$ (AOAC 1984). The acidity percentage was calculated as mg anhydrous citric acid per 100 milliliters of juice .The total soluble solids (TSS) was determined as \% in juice by means of hand refractometer. The TSS / Acid ratio was calculated.

\section{Leaf mineral content}

Dry leaves which collected to determine chlorophyll content and leaf dry matter \% were grounded and digested using sulphoric acid and oxygen peroxide to determine $\mathrm{N}, \mathrm{P}, \mathrm{K}, \mathrm{Fe}, \mathrm{Zn}$ and Mn. Nitrogen was determined by the MicroKjeldahlmethod ,phosphorus was determined by the spectrophotometer, potassium was determined by a flame photometer (Jackson, 1973). Iron, zinc and manganese were estimated by using an atomic absorption according to the method of (Cottenie et al., 1982).

\section{Statistical analysis}

The obtained data were statistically analyzed by using the analysis of variance as reported by (Snedecor and Cochran, 1980). Means were differentiated by using Duncan's multiple range tests at $5 \%$ (Duncan, 1955).

\section{$\underline{\text { Results and Discussion }}$}

Effect on leaf chlorophyll content and leaf dry matter (\%) of wonderful pomegranate

Results in Table 2 show that, the effect of humic acid, nitrogen fertilizers sources and their 
interaction on chlorophyll content and leaf dry matter \% during 2015, 2016 and 2017 seasons. Results concerning chlorophyll content revealed that, chlorophyll content was affected significantly by humic acid in the second and third seasons only, but with contrary effect. Whereas, chlorophyll content it was affected by nitrogen sources in the three seasons, while cattle manure recorded the least values in the three seasons. On the other hand the highest values were obtained by mineral nitrogen (treatments $1 \& 2 ; 40$ and $80 \mathrm{~kg} \mathrm{~N} / \mathrm{fed} /$ year). Regarding the interaction, in most cases, two mineral nitrogen treatments without humic acid gave the highest values of chlorophyll content. Whereas, cattle manure without humic gave the lowest values in the three seasons.

Leaf dry matter percentage was significantly affected by humic acid, the highest significant values observed by control trees especially in the first and third seasons. Regarding the effects of nitrogen sources and the interaction it was difficult to observe a constant trend.

In this respect, (Eman et al., 2010), who reported that the combination between $50 \%$ of the recommended rate of mineral nutrients $(1 \mathrm{Kg}$ ammonium sulphate $+0.5 \mathrm{Kg}$ potassium sulphate $+0.5 \mathrm{Kg}$ super phosphate/tree) +humic acid $25 \mathrm{~g} /$ tree gave the best results for all vegetative growth measurements of Arabi pomegranate trees while when this treatment was combined with humic acid at lower concentration $12.5 \mathrm{~g} /$ tree or compost at rate of $25 \mathrm{Kg} /$ tree the results showed intermediate values of vegetative growth parameters.

Effect on fruit weight, fruit number and yield of wonderful pomegranate

Results in Table 3 show that, the effect of humic acid, nitrogen fertilizers sources and their interaction on fruit weight, fruit number and yield

TABLE 2. Effect of humic acid and some nitrogen fertilizers sources on leaf chlorophyll and leaf dry matter of wonderful pomegranate trees during 2015, 2016 and 2017 seasons.

\begin{tabular}{|c|c|c|c|c|c|c|}
\hline \multicolumn{7}{|c|}{ Humic acid (50g/tree/year) } \\
\hline \multirow{2}{*}{ Nitrogen fertilizers sources } & Without & With & Mean & Without & With & Mean \\
\hline & \multicolumn{3}{|c|}{ Leaf chlorophyll (SPAD) } & \multicolumn{3}{|c|}{ Leaf dry matter \% } \\
\hline & \multicolumn{6}{|c|}{2015 season } \\
\hline Chicken manure & $63.6 \mathrm{c}$ & $62.6 \mathrm{~cd}$ & $63.1 \mathrm{BC}^{\prime}$ & $45.5 \mathrm{de}$ & $45.5 \mathrm{de}$ & $45.5 \mathrm{~B}^{\prime}$ \\
\hline Compost & $58.7 \mathrm{~cd}$ & $61.2 \mathrm{~cd}$ & $60.0 \mathrm{C}^{\prime}$ & $44.5 \mathrm{e}$ & $43.9 \mathrm{e}$ & $44.2 B^{\prime}$ \\
\hline Cattle manure & $55.9 \mathrm{~d}$ & $63.2 \mathrm{c}$ & $59.5 \mathrm{C}^{\prime}$ & $54.5 \mathrm{a}$ & $43.4 \mathrm{c}$ & $49.0 \mathrm{~A}^{\prime}$ \\
\hline Mineral 1 & $71.1 \mathrm{a}$ & $64.4 \mathrm{bc}$ & $67.8 \mathrm{~A}^{\prime}$ & $51.3 \mathrm{bc}$ & $49.0 \mathrm{c}$ & $50.2 \mathrm{~A}^{\prime}$ \\
\hline Mineral 2 & $70.5 \mathrm{ab}$ & $63.3 \mathrm{c}$ & $66.9 \mathrm{AB}^{\prime}$ & $53.3 \mathrm{ab}$ & $47.3 \mathrm{~cd}$ & $50.3 \mathrm{~A}^{\prime}$ \\
\hline \multirow[t]{2}{*}{ Mean } & $64.0 \mathrm{~A}$ & $63.0 \mathrm{~A}$ & & $50.0 \mathrm{~A}$ & $45.8 \mathrm{~B}$ & \\
\hline & \multicolumn{6}{|c|}{2016 season } \\
\hline Chicken manure & $59.4 \mathrm{ab}$ & $60.0 \mathrm{a}$ & $59.7 \mathrm{~A}^{\prime}$ & $29.8 b$ & $54.6 \mathrm{a}$ & $42.2 \mathrm{~A}^{\prime}$ \\
\hline Compost & $57.3 \mathrm{ab}$ & $58.9 \mathrm{ab}$ & $58.2 \mathrm{AB}^{\prime}$ & $31.8 \mathrm{ab}$ & $42.5 \mathrm{ab}$ & $37.2 \mathrm{~A}^{\prime}$ \\
\hline Cattle manure & $52.3 b$ & $55.0 \mathrm{ab}$ & $53.7 \mathrm{~B}^{\prime}$ & $49.9 \mathrm{ab}$ & $33.5 \mathrm{ab}$ & $41.7 \mathrm{~A}^{\prime}$ \\
\hline Mineral 1 & $56.4 \mathrm{ab}$ & $60.0 \mathrm{a}$ & $58.2 \mathrm{AB}^{\prime}$ & $36.2 \mathrm{ab}$ & $44.2 \mathrm{ab}$ & $40.2 \mathrm{~A}^{\prime}$ \\
\hline Mineral 2 & $54.1 \mathrm{ab}$ & $58.7 \mathrm{ab}$ & $56.4 \mathrm{AB}^{\prime}$ & $37.3 \mathrm{ab}$ & $43.2 \mathrm{ab}$ & $40.2 \mathrm{~A}^{\prime}$ \\
\hline \multirow[t]{2}{*}{ Mean } & $55.9 \mathrm{~B}$ & $58.5 \mathrm{~A}$ & & $37.0 \mathrm{~A}$ & $43.6 \mathrm{~A}$ & \\
\hline & \multicolumn{6}{|c|}{2017 season } \\
\hline Chicken manure & $64,6 b$ & $61.5 b c$ & $63.0 \mathrm{~B}^{\prime}$ & $48.3 \mathrm{bc}$ & $42.8 \mathrm{de}$ & $44.2 \mathrm{~A}^{\prime}$ \\
\hline Compost & $61.8 \mathrm{bc}$ & $60.7 \mathrm{bc}$ & $61.3 \mathrm{~B}^{\prime}$ & $45.5 b-d$ & $41.5 \mathrm{e}$ & $43.7 \mathrm{~B}^{\prime}$ \\
\hline Cattle manure & $56.1 \mathrm{~d}$ & $59.3 \mathrm{~cd}$ & $57.7 C^{\prime}$ & $45.9 \mathrm{~d}-\mathrm{d}$ & $40.7 \mathrm{e}$ & $43.0 \mathrm{~B}^{\prime}$ \\
\hline Mineral 1 & $64.0 \mathrm{bc}$ & $61.7 b c$ & $62.8 \mathrm{~B}^{\prime}$ & $49.0 \mathrm{~b}$ & $48.3 b c$ & $48.7 \mathrm{~A}^{\prime}$ \\
\hline Mineral 2 & $69.3 \mathrm{a}$ & $64.0 \mathrm{bc}$ & $66.7 \mathrm{~A}^{\prime}$ & $53.3 \mathrm{a}$ & $46.3 b-d$ & $48.8 \mathrm{~A}^{\prime}$ \\
\hline Mean & $63.2 \mathrm{~A}$ & $61.4 \mathrm{~B}$ & & $47.8 \mathrm{~A}$ & $44.0 \mathrm{~B}$ & \\
\hline
\end{tabular}

In each season, means of each of humic acid and nitrogen fertilizers sources or their interactions having the same letters are not significantly different at $5 \%$ level. 
TABLE 3. Effect of humic acid and some nitrogen fertilizers sources on fruit weight, fruit number /tree and yield of wonderful pomegranate trees during 2015, 2016 and 2017seasons

\begin{tabular}{|c|c|c|c|c|c|c|c|c|c|}
\hline \multicolumn{10}{|c|}{ Humic acid (50g/tree/year) } \\
\hline \multirow{3}{*}{$\begin{array}{l}\text { Nitrogen } \\
\text { fertilizers sources }\end{array}$} & Without & With & Mean & Without & With & Mean & Without & With & Mean \\
\hline & \multicolumn{3}{|c|}{ Fruit weight (g) } & \multicolumn{3}{|c|}{ Fruits number /tree } & \multicolumn{3}{|c|}{ Yield (kg /tree) } \\
\hline & \multicolumn{9}{|c|}{2015 season } \\
\hline Chicken manure & $498.9 \mathrm{ab}$ & $508.9 \mathrm{ab}$ & $503.9 \mathrm{~A}^{\prime}$ & $71.7 \mathrm{a}$ & $61.7 \mathrm{ab}$ & $66.7 \mathrm{~A}^{\prime}$ & $34.9 \mathrm{a}$ & $30.0 \mathrm{~b}$ & $32.9 \mathrm{~A}^{\prime}$ \\
\hline Compost & $546.7 \mathrm{ab}$ & $454.4 b$ & $500.6 A^{\prime}$ & $63.5 \mathrm{ab}$ & $67.9 \mathrm{ab}$ & $65.7 \mathrm{~A}^{\prime}$ & $34.7 \mathrm{a}$ & $30.8 \mathrm{~b}$ & $32.8 \mathrm{~A}^{\prime}$ \\
\hline Cattle manure & $565.6 \mathrm{ab}$ & $540.0 \mathrm{ab}$ & $552.8 \mathrm{~A}^{\prime}$ & $40.5 \mathrm{c}$ & $41.2 \mathrm{c}$ & $40.8 C^{\prime}$ & $22.3 f$ & $22.0 \mathrm{f}$ & $22.3 \mathrm{C}^{\prime}$ \\
\hline Mineral 1 & $570.0 \mathrm{a}$ & $487.4 \mathrm{ab}$ & $528.7 \mathrm{~A}^{\prime}$ & $44.3 \mathrm{c}$ & $58.7 \mathrm{ab}$ & $49.3 \mathrm{~B}^{\prime}$ & $25.2 \mathrm{de}$ & $28.3 \mathrm{c}$ & $26.7 \mathrm{~B}^{\prime}$ \\
\hline Mineral 2 & $558.9 \mathrm{ab}$ & $480.0 \mathrm{ab}$ & $519.4 \mathrm{~A}^{\prime}$ & $42.07 \mathrm{c}$ & $56.6 \mathrm{~b}$ & $51.5 \mathrm{~B}^{\prime}$ & $24.2 \mathrm{ef}$ & $27.0 \mathrm{~cd}$ & $25.6 \mathrm{~B}^{\prime}$ \\
\hline \multirow[t]{2}{*}{ Mean } & $548.0 \mathrm{~A}$ & $494.2 B$ & & $52.4 \mathrm{~A}$ & $57.2 \mathrm{~A}$ & & $28.3 \mathrm{~A}$ & $27.8 \mathrm{~A}$ & \\
\hline & \multicolumn{9}{|c|}{2016 season } \\
\hline Chicken manure & $536.7 \mathrm{a}$ & $480.4 \mathrm{ab}$ & $508.5 \mathrm{~A}^{\prime}$ & $53.7 \mathrm{~cd}$ & $62.7 b$ & $58.2 \mathrm{~B}^{\prime}$ & $32.3 \mathrm{a}$ & $30.2 \mathrm{ab}$ & $31.2 \mathrm{~A}^{\prime}$ \\
\hline Compost & $532.5 \mathrm{a}$ & $494.2 \mathrm{ab}$ & $513.3 \mathrm{~A}^{\prime}$ & $57.0 \mathrm{c}$ & $57.3 \mathrm{c}$ & $57.2 \mathrm{~B}^{\prime}$ & $30.3 \mathrm{ab}$ & $28.3 \mathrm{a}-\mathrm{c}$ & $29.3 \mathrm{AB}^{\prime}$ \\
\hline Cattle manure & $424.2 \mathrm{bc}$ & $389.2 \mathrm{ab}$ & $406.7 \mathrm{~B}^{\prime}$ & $50.0 \mathrm{~d}$ & $56.7 \mathrm{c}$ & $53.3 C^{\prime}$ & $21.2 \mathrm{~d}$ & $22.02 \mathrm{~cd}$ & $21.6 C^{\prime}$ \\
\hline Mineral 1 & $430.8 b c$ & $390.0 \mathrm{c}$ & $385.4 \mathrm{~B}^{\prime}$ & $57.7 \mathrm{c}$ & $67.3 \mathrm{a}$ & $62.5 \mathrm{~A}^{\prime}$ & $24.8 b-d$ & $26.3 a-d$ & $25.6 \mathrm{BC}^{\prime}$ \\
\hline Mineral 2 & $420.8 b c$ & $350.0 \mathrm{c}$ & $410.5 \mathrm{~B}^{\prime}$ & $54.3 \mathrm{~cd}$ & $66.0 \mathrm{ab}$ & $60.2 \mathrm{AB}^{\prime}$ & $22.9 \mathrm{~cd}$ & $23.2 \mathrm{~cd}$ & $23.0 \mathrm{C}^{\prime}$ \\
\hline \multirow[t]{2}{*}{ Mean } & $469.0 \mathrm{~A}$ & $420.8 \mathrm{~B}$ & & $54.5 \mathrm{~B}$ & $62.0 \mathrm{~A}$ & & $26.3 \mathrm{~A}$ & $26.0 \mathrm{~A}$ & \\
\hline & \multicolumn{9}{|c|}{2017 season } \\
\hline Chicken manure & $485.6 \mathrm{a}-\mathrm{c}$ & $570.0 \mathrm{a}$ & $527.8 \mathrm{~A}^{\prime}$ & $59.7 \mathrm{a}$ & $54.0 \mathrm{a}-\mathrm{d}$ & $56.8 \mathrm{~A}^{\prime}$ & $28.9 \mathrm{a}-\mathrm{c}$ & $30.6 \mathrm{ab}$ & $29.8 \mathrm{~A}^{\prime}$ \\
\hline Compost & $546.7 \mathrm{ab}$ & $505.6 \mathrm{a}-\mathrm{c}$ & $526.1 \mathrm{~A}^{\prime}$ & $57.7 \mathrm{ab}$ & $56.7 \mathrm{a}-\mathrm{c}$ & $57.2 \mathrm{~A}^{\prime}$ & $31.2 \mathrm{ab}$ & $28.6 a-c$ & $29.9 \mathrm{~A}^{\prime}$ \\
\hline Cattle manure & $400.0 \mathrm{bc}$ & $393.3 \mathrm{c}$ & $396.7 B^{\prime}$ & $52.0 \mathrm{~b}-\mathrm{d}$ & $51.3 b-d$ & $51.7 \mathrm{~B}^{\prime}$ & $20.7 d$ & $20.3 d$ & $20.5 B^{\prime}$ \\
\hline Mineral 1 & $515.6 a-c$ & $457.8 \mathrm{a}-\mathrm{c}$ & $486.7 \mathrm{AB}^{\prime}$ & $50.3 \mathrm{~cd}$ & $51.3 b-d$ & $50.8 \mathrm{~B}^{\prime}$ & $26.0 \mathrm{a}-\mathrm{d}$ & $23.5 b-d$ & $24.8 \mathrm{~B}^{\prime}$ \\
\hline Mineral 2 & $504.4 a-c$ & $453.6 \mathrm{a}-\mathrm{c}$ & $470.0 \mathrm{AB}^{\prime}$ & $50.0 \mathrm{~d}$ & $49.7 \mathrm{~d}$ & $49.8 \mathrm{~B}^{\prime}$ & $25.2 \mathrm{a}-\mathrm{d}$ & $21.7 \mathrm{~cd}$ & $23.5 \mathrm{~B}^{\prime}$ \\
\hline Mean & 490.4A & $472.5 \mathrm{~A}$ & & $53.9 \mathrm{~A}$ & $52.6 \mathrm{~A}$ & & $26.4 \mathrm{~A}$ & $25.0 \mathrm{~B}$ & \\
\hline
\end{tabular}

In each season, means of each of humic acid and nitrogen fertilizers sources or their interactions having the same letters are not significantly different at 5\% level.

of pomegranate trees during 2015, 2016 and 2017 seasons.

Results showed that in the first and second seasons only fruit weight was affected significantly by humic acid whereas, control trees gave the higher values than treated one. Fruit weight was affected significantly by nitrogen fertilizers sources especially in the second and third seasons whereas, chicken manure and compost gave the higher values than other treatments, followed closely by mineral nitrogen treatments (1 and 2) in the third season. Regarding the interaction, the results indicated that, combining compost or chicken manure with or without humic gave the highest value as compared with other combinations especially in the second and third seasons.

Fruit number was significantly affected by humic acid levels in second season only and treated trees gave the highest values. The results showed that, in the three seasons fruit number was significantly affected with nitrogen fertilizers sources whereas, chicken manure and compost gave the higher values than other treatments epically, in the first and third season. On the other hand, cattle manure gave the lowest significant values especially in the first and second seasons. Regarding the interaction the trend was clearer in first and third seasons whereas, chicken manure and compost with or without humic treatments gave the highest significant values. On the other hand, in most cases cattle manure with or without humic treatments gave lower values than other treatments.

Yield was insignificantly affected by humic acid levels while in the third season control trees gave the highest significant value as compared with treated one. Regarding nitrogen fertilizers sources it was clear that, in three seasons chicken manure and compost gave the highest significant values. On the other hand, cattle manure gave Egypt. J. Hort. Vol. 45, No. 1 (2018) 


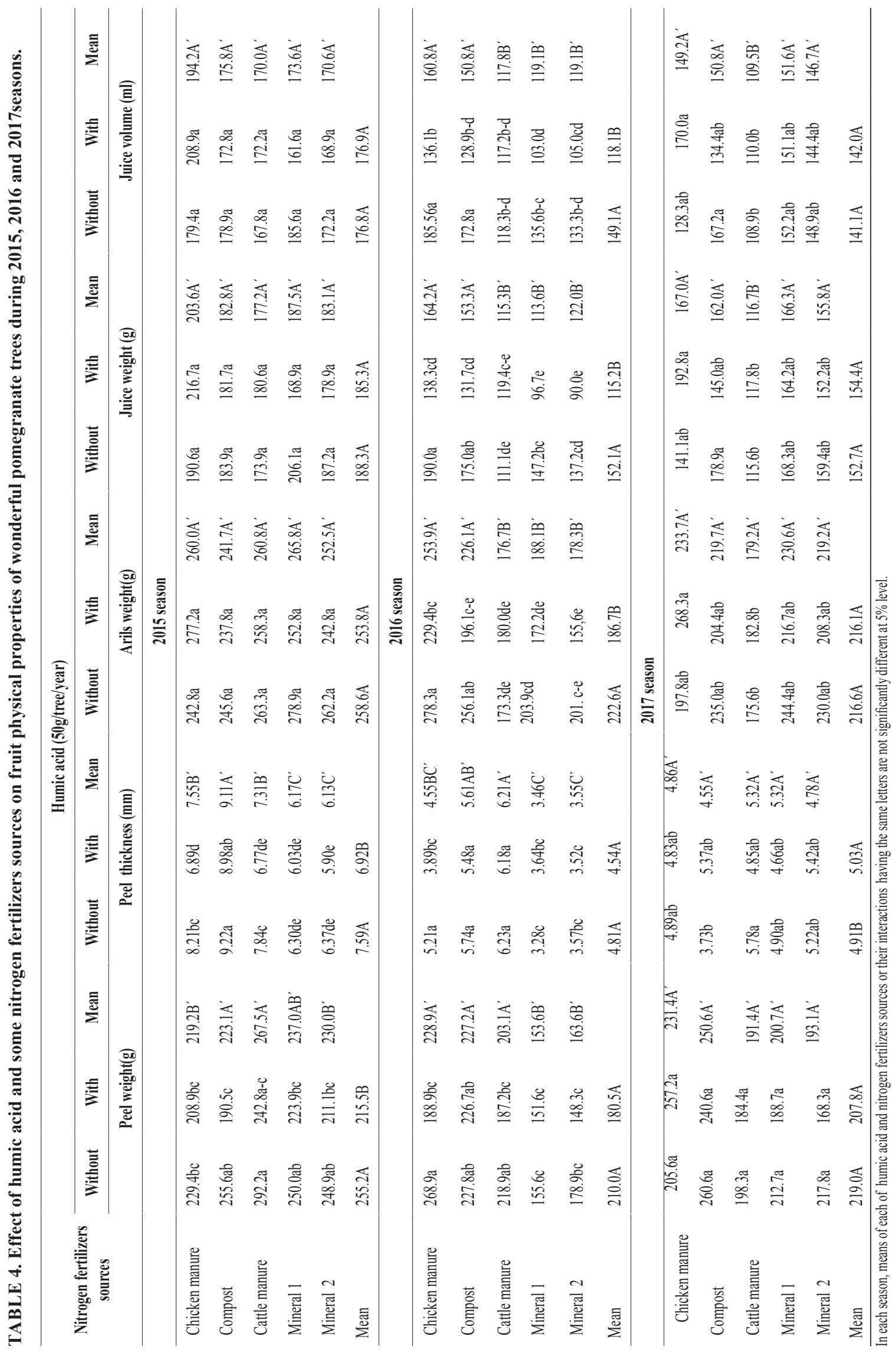

Egypt. J. Hort. Vol. 45, No. 1 (2018) 
the least values. The data of interaction revealed that, combining compost or chicken manure with or without humic gave higher values than other combinations especially in the second and third seasons. While, cattle manure with or without humic gave lower values than mineral treatments (40 and $80 \mathrm{~kg} \mathrm{~N} /$ fed /year).

These results are in line with those obtained by (Altieri and Nicholls, 2003), who reported that, soil organic matter has been positively correlated to the soil fertility and crops productivity. Soils with high organic matters, in most cases exhibit good soil fertility and crops grown in such soils generally exhibit lower abundance of several insect. Moreover, (Eman et al., 2010) revealed that, $50 \%$ of the recommended rate of NPK $(1 \mathrm{Kg}$ ammonium sulphate $+0.5 \mathrm{Kg}$ potassium sulphate $+0.5 \mathrm{Kg}$ super phosphate) /tree) + humic acid at $25 \mathrm{~g} /$ tree gave the highest significant values of fruit numbers, fruit weight and yield of Arabi pomegranate trees than other treatments. On the other hand, Marzouk and Kassem (2011) found that, the application of organic manures (chicken manure, cow dung and composted domestic refuse either alone or in combinations with mineral NPK on Zaghloul dates did not differ from each other in their effect on yield and fruit quality. While, Magda et al., (2012) found that, increasing humic acid doses from 32 to $48 \mathrm{~g} /$ tree enhanced vegetative growth and all yield and fruiting parameters of Manfalouty pomegranate trees.

\section{Effect on fruit physical properties of wonderful pomegranate}

Results in Tables 4 and 5 show the effect of humic acid, nitrogen fertilizers sources and their interactions on some fruit physical properties of pomegranate in 2015, 2016 and 2017 seasons.

Concerning, peel weight was affected significantly by humic acid levels in first season only and control trees gave higher values than treated one. On the other hand, peel weight was affected significantly by nitrogen fertilizers sources in the first and second seasons only and in general different organic nitrogen sources (chicken manure, compost and cattle manure) gave the highest values followed by mineral treatment (40kg N/fed /year). Regarding the interaction, the peel weight affected significantly by interaction in the first and second seasons only whereas, compost and cattle manure without humic gave the higher values than most other treatments in both seasons expect chicken manure in the second season.
Peel thickness was affected significantly by humic acid levels in the first season and the third seasons but with contrary trend. Regarding nitrogen fertilizers sources the highest significant values were obtained by compost in the first and the second seasons followed by chicken manure and cattle manure in the second season. Other treatment gave more or less similar values with the same statically stand point. The interaction was clearer in the first and in the second seasons and compost with or without humic gave the highest values in both season followed by cattle manure with or without humic treatments and chicken manure without humic treatment in the second season.

Arils weight was affected significantly by humic acid levels in the second season only, whereas untreated trees gave the higher value than treated one. Arils weight was significantly affected by nitrogen fertilizers sources in the second season only, whereas chicken manure gave the highest significant followed closely by compost. Other treatment gave more or less similar values with the same statically stand point. The effect of interaction was clear in the second season whereas chicken manure and compost without humic gave the highest significant values.

Results concerning juice weight and juice volume indicated that, two characters were significantly affected by humic acid levels in the second season only, whereas untreated trees gave the higher value than treated one. It was observed that, the highest values of juice weight and juice volume were obtained by chicken manure and compost in the second and the third season followed closely by mineral treatments (40 and $80 \mathrm{~kg} \mathrm{~N} /$ fed /year) especially in the third season. Results revealed that the interaction was significant in the second and the third seasons. Whereas, the highest significantly values were obtained by (chicken manure, compost and mineral 1 \&2) with or without humic application.

From the results in Table 5, it could be concluded that humic acid addition in most cases was lacked significance on physical properties percentage of wonderful pomegranate fruit (arils/ fruit weight $\%$, juice/fruit weight $\%$ and juice /arils weight). On the other hand, physical properties percentage of fruit were significantly affected by nitrogen fertilizers sources especially in the first and in the third seasons and the highest values were obtained by chicken manure and compost fertilizers followed by two mineral levels (40 and $80 \mathrm{~kg} \mathrm{~N} /$ fed /year). While, cattle manure fertilizer gave the lowest significant values in most cases. 
Regarding the combination between humic and nitrogen fertilizers in most cases, it is clear that physical properties percentage of wonderful pomegranate were increased by chicken manure and compost fertilizers followed by two mineral treatments under both humic levels.

In this respect (Abd El-Rhman, 2017 ) studied on, Manfalouty pomegranate trees and pointed out that magnetic iron at $100 \mathrm{~g}$ or $200 \mathrm{~g}$ /tree and potassium humate at $25 \mathrm{~g}$ or $50 \mathrm{~g} /$ tree treatment gave the highest significant values of fruit grain percentage while the lowest values were obtained from untreated trees in both seasons.

Effect on some fruit chemical properties of wonderful pomegranates: Results in Table 6 show that, the effect of humic acid, nitrogen fertilizers sources and their interactions on fruit chemical properties of wonderful pomegranates trees in 2015, 2016 and 2017seasons.
TSS was significantly affected by humic acid levels in the second and in the third seasons but with contrary trend. On the other hand, TSS was significantly affected by nitrogen fertilizers sources whereas, compost gave the highest values of TSS in the three seasons followed closely by mineral treatments (40 and $80 \mathrm{~kg} \mathrm{~N} / \mathrm{fed} /$ year) in the first and in the second seasons and with chicken manure fertilizer in the third season. Regarding the interaction the lowest values were obtained when combing cattle manure with humic (50 g humic/tree/year). In most cases, the highest values were obtained by chicken manure and compost fertilizers followed closely by two mineral treatments under both humic levels.

Acidity was significantly affected by humic application and $50 \mathrm{~g}$ humic/tree/year gave the highest significant values especially in the second and in the third seasons. In the most cases, chicken manure fertilizer gave the lowest values

TABLE 5. Effect of humic acid and some nitrogen fertilizers sources on some fruit physical properties percentage of wonderful pomegranate trees during 2015, 2016 and 2017seasons.

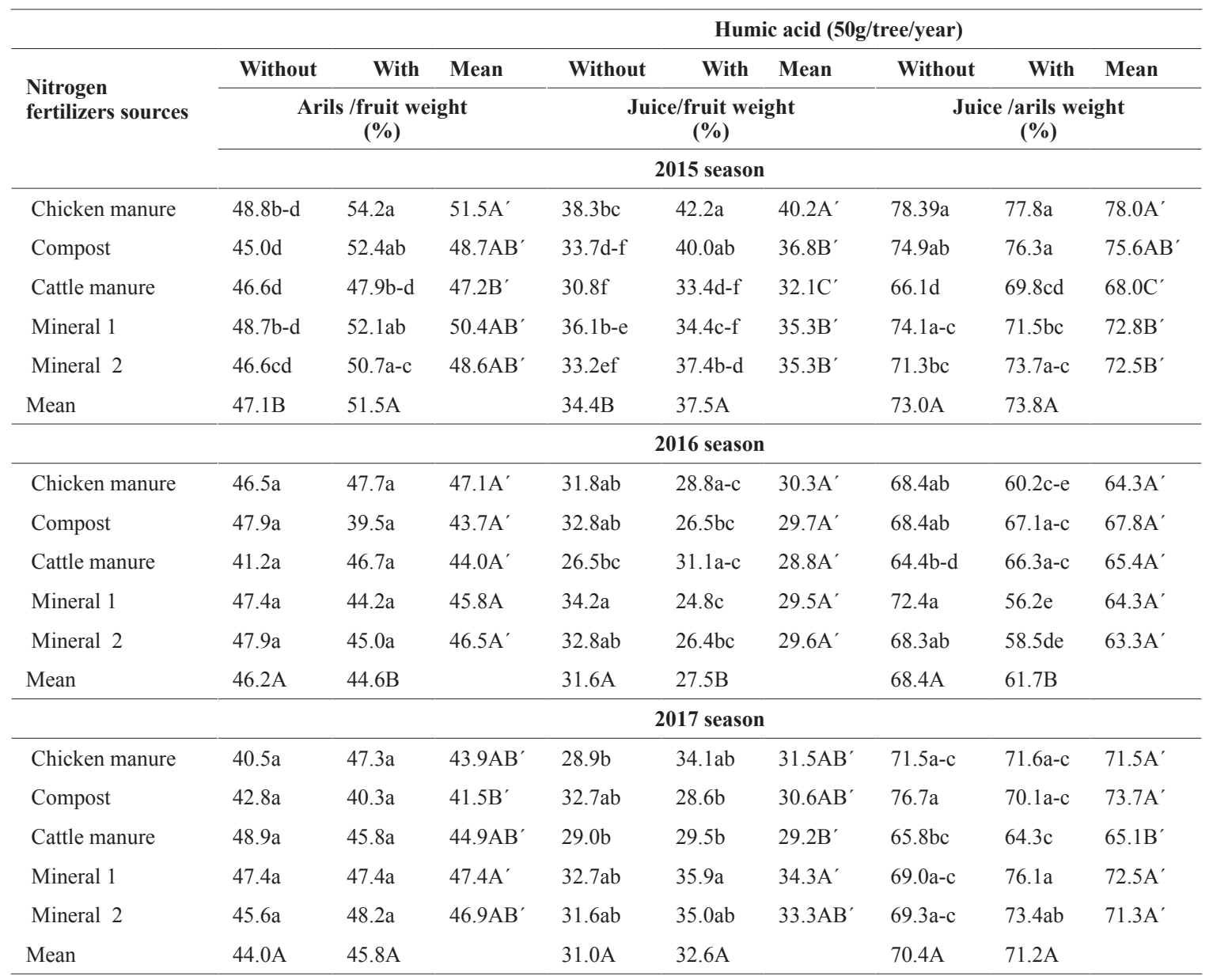

In each season, means of each of humic acid and nitrogen fertilizers sources or their interactions having the same letters are not significantly different at $5 \%$ level.

Egypt. J. Hort. Vol. 45, No. 1 (2018) 


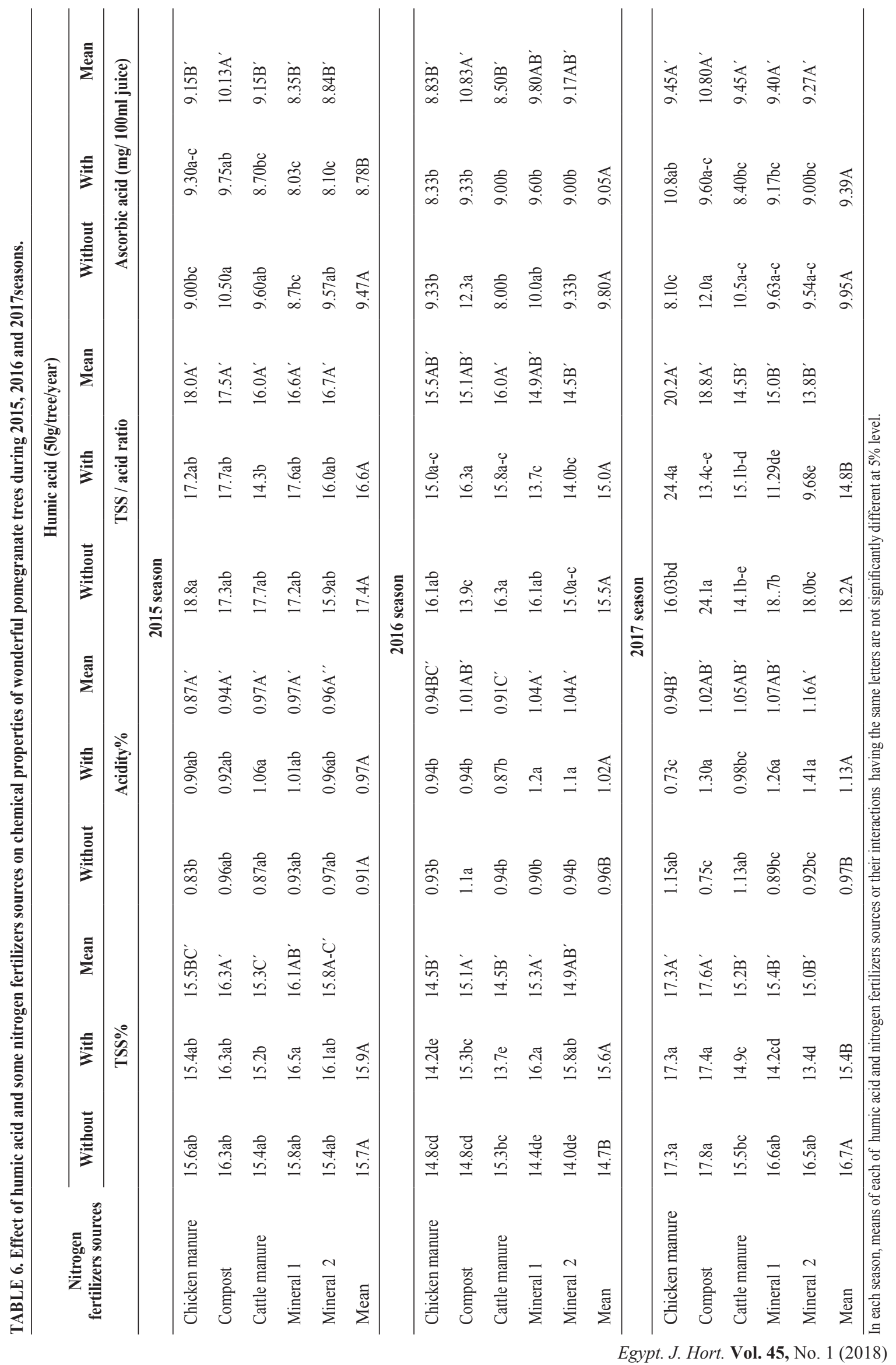


of acidity. On the other hand, mineral (1 and 2) treatments gave the highest values followed by compost. Regarding the interaction, the highest values were obtained when combing mineral (1 or 2) with humic (50 g humic/tree/year) especially in the second and third seasons.

Humic acid application did not affect TSS / acid ratio in the first and second seasons, but it reduced TSS / acid ratio markedly in the third season. On the other hand, TSS / acid ratio was significantly affected by nitrogen fertilizers sources especially in the second and third seasons and the highest values were obtained by chicken manure and compost fertilizers compared with two mineral levels (40 and $80 \mathrm{~kg} \mathrm{~N} /$ fed /year). Regarding the interaction, it was difficult to find a specific trend.

Data concerning ascorbic acid showed that, humic acid affected significantly on ascorbic acid in the first season only and the highest significant values were obtained by untreated trees compared to treated one. The highest values of ascorbic acid were obtained by compost fertilizer. With respect to combination between humic acid and nitrogen fertilizers sources, it is observed that, in the three seasons the highest values were obtained by compost under the first level of humic treatment. Some other treatments gave more or less similar values with the same statistical stand point.

In this respect, Fathy et al. (2010) pointed out that, humic acid (foliar and soil applications) treatments gave the highest values of yield and fruit physical and chemical properties (fruit firmness, juice SSC and SSC/acidity ratio) of 'Canino' apricot. On the other hand, Duttaray et al. (2014) reported that, pomegranate cultivar "Ganesh" trees treated with $300 \mathrm{~g}$ nitrogen in the form of urea $+1 \mathrm{~kg}$ neem cake plant ${ }^{-1}$ gave highest values of TSS, total sugar, reducing sugar, nonreducing sugar and ascorbic acid. Acidity was also recorded the least values with this treatment.

\section{Effect on leaf macronutrients content}

Results in Table 7 showed that, the effect of humic acid, nitrogen fertilizers sources and their interactions on $\mathrm{N}, \mathrm{P}$ and $\mathrm{K}$ content in leaves of wonderful pomegranates trees in 2015, 2016 and 2017seasons.

Results proved that, nitrogen content was insignificantly affected by the humic acid addition except in the first season. It was clear that, chicken manure and compost gave the highest values of nitrogen in three seasons, respectively. Regarding the interactions, the highest values of nitrogen content were obtained by chicken manure and compost with or without humic treatments Egypt. J. Hort. Vol. 45, No. 1 (2018) especially in the second season. In the most cases, cattle manure with or without humic treatments gave the least values of nitrogen content. On the other hand, mineral treatments (40 and $80 \mathrm{~kg} \mathrm{~N} /$ fed/year) with or without humic gave intermediate values between above treatment.

Concerning, phosphorus content the data revealed that $\mathrm{P}$ content was significantly affected by humic levels and $50 \mathrm{~g}$ humic/tree/year level gave the least values of $\mathrm{P}$ content during three seasons. On the other hand, compost gave the higher values of phosphorus content than other treatments except in the second season. Regarding the interaction, in the first and in the third seasons, chicken manure with humic acid at $50 \mathrm{~g} /$ tree/ year gave the least significant values of $\mathrm{P}$ content. Other treatment gave more or less similar values with the same statically stand point.

Potassium content was insignificantly affected by humic levels in the three seasons. On the other hand, mineral treatments (40 and $80 \mathrm{~kg} \mathrm{~N} / \mathrm{fed} /$ year) gave the highest values of $\mathrm{K}$ content followed closely by chicken manure and compost in the first and in the second season, respectively. Results revealed that the interaction was significant in the three seasons. The trend was clearer in the second season than other seasons whereas, the highest values of $\mathrm{K}$ were obtained by chicken manure and compost under any level of humic.

In this respect, Fayed (2005) pointed out that application of different organic manures on "Anna" apple trees increased leaf NPK contents as compared with control trees. Moreover, Fawzi et al., (2010) reported that individual addition of compost and cow manure as well as their combinations with biofertilizer increased $\mathrm{N}, \mathrm{P}$, $\mathrm{K}$, and $\mathrm{Mg}$ contents of "Le-Conte" pear leaves. Also, Barakat et al., (2012) reported that, organic fertilizers plus humic acid or EM increasing NPK content in Newhall navel orange leaves compared with the chemical fertilizers.

\section{Effect on leaf micronutrients content}

Results in Table 8 showed that, the effect of humic acid, nitrogen fertilizers sources and their interactions on $\mathrm{Fe}, \mathrm{Zn}$ and $\mathrm{Mn}$ content in leaves of wonderful pomegranates trees in 2015, 2016 and 2017seasons.

Results concerning, iron content was affected by humic addition in second season only whereas; untreated trees gave the higher values than treated one. It is obvious that iron content was increased by fertilizing with compost which gave the highest values especially in the first and in the third seasons. From the interactions values 
in three seasons it could be concluded that the highest values of iron content were obtained by compost without humic acid application in the three seasons In most cases other treatments gave more or less similar values with the same statically stand point especially in the first and third seasons.

Results revealed that, zinc content was significantly affected by humic addition in the second season only whereas, untreated trees gave the highest significant value of leaf zinc content. On the other hand, zinc content was affected significantly by nitrogen sources in the first two seasons whereas, compost gave the highest values followed by cattle manure and (chicken manure \& mineral 1) in the first and second season, respectively. It is observed that, all organic nitrogen fertilizers gave the highest values of leaf zinc content under any level of humic especially in the first and in the third seasons.
Values of manganese content were significantly affected by levels of humic in the first season only. With respect to nitrogen fertilizers sources the highest values of manganese content were obtained by chicken manure and compost fertilizers followed closely by mineral 1 and mineral 2 in the second and in the third seasons. Interactions results were varied from season to another but the trend was clearer in the first season whereas, chicken manure and compost with humic at $50 \mathrm{~g} /$ tree/year gave the highest significant values of manganese content in leaf.

Ali et al., 2017 revealed that, granule humic ( $2 \mathrm{~kg} /$ tree) application on six years old pomegranate trees cv. 'Bajestani' effectively promoted nutrient uptake from soil and gave the highest values of $\mathrm{N}, \mathrm{K}, \mathrm{Mg}, \mathrm{Fe}$, and $\mathrm{Zn}$ content in the leaves of treated plants.

TABLE 7. Effect of humic acid and some nitrogen fertilizers sources on $N, P$ and $K$ content in leaves of wonderful pomegranate trees during 2015, 2016 and 2017 seasons.

\begin{tabular}{|c|c|c|c|c|c|c|c|c|c|}
\hline \multicolumn{10}{|c|}{ Humic acid (50g/tree/year) } \\
\hline \multirow{3}{*}{$\begin{array}{l}\text { Nitrogen } \\
\text { fertilizers sources }\end{array}$} & Without & With & Mean & Without & With & Mean & Without & With & Mean \\
\hline & & $\mathbf{N} \%$ & & \multicolumn{3}{|c|}{$\mathbf{P \%}$} & \multicolumn{3}{|c|}{$\mathbf{K} \%$} \\
\hline & \multicolumn{9}{|c|}{2015 season } \\
\hline Chicken manure & $1.88 \mathrm{ab}$ & $1.71 \mathrm{a}-\mathrm{c}$ & $1.79 \mathrm{AB}^{\prime}$ & $0.16 \mathrm{ab}$ & $0.12 b$ & $0.14 \mathrm{~B}^{\prime}$ & $0.62 a-c$ & $0.66 \mathrm{ab}$ & $0.64 \mathrm{AB}^{\prime}$ \\
\hline Compost & $1.97 \mathrm{a}$ & $1.80 \mathrm{a}-\mathrm{c}$ & $1.88 \mathrm{~A}^{\prime}$ & $0.26 \mathrm{a}$ & $0.24 \mathrm{a}$ & $0.25 \mathrm{~A}^{\prime}$ & $0.64 \mathrm{ab}$ & $0.53 \mathrm{c}$ & $0.58 \mathrm{~B}^{\prime}$ \\
\hline Cattle manure & $1.58 \mathrm{a}-\mathrm{c}$ & $1.54 \mathrm{bc}$ & $1.56 \mathrm{~B}^{\prime}$ & $0.16 \mathrm{ab}$ & $0.16 \mathrm{ab}$ & $0.16 \mathrm{~B}^{\prime}$ & $0.59 b c$ & $0.62 \mathrm{a}-\mathrm{c}$ & $0.60 \mathrm{~B}^{\prime}$ \\
\hline Mineral 1 & $1.67 \mathrm{a}-\mathrm{c}$ & $1.41 \mathrm{c}$ & $1.54 \mathrm{~B}^{\prime}$ & $0.17 \mathrm{ab}$ & $0.16 \mathrm{ab}$ & $0.17 \mathrm{~B}^{\prime}$ & $0.67 \mathrm{ab}$ & $0.72 \mathrm{a}$ & $0.70 \mathrm{~A}^{\prime}$ \\
\hline Mineral 2 & $1.80 \mathrm{a}-\mathrm{c}$ & $1.58 \mathrm{a}-\mathrm{c}$ & $1.69 \mathrm{AB}^{\prime}$ & $0.17 \mathrm{ab}$ & $0.15 \mathrm{ab}$ & $0.16 \mathrm{~B}^{\prime}$ & $0.61 b c$ & $0.66 \mathrm{ab}$ & $0.63 \mathrm{AB}^{\prime}$ \\
\hline \multirow[t]{2}{*}{ Mean } & $1.78 \mathrm{~A}$ & $1.61 \mathrm{~B}$ & & $0.18 \mathrm{~A}$ & $0.17 \mathrm{~B}$ & & $0.63 \mathrm{~A}$ & $0.64 \mathrm{~A}$ & \\
\hline & \multicolumn{9}{|c|}{2016 season } \\
\hline Chicken manure & $1.80 \mathrm{a}$ & $1.58 \mathrm{a}-\mathrm{c}$ & $1.69 \mathrm{~A}^{\prime}$ & $0.14 \mathrm{e}$ & $0.14 \mathrm{e}$ & $0.14 \mathrm{C}^{\prime}$ & $0.77 \mathrm{a}$ & $0.70 \mathrm{a}-\mathrm{c}$ & $0.74 \mathrm{~A}^{\prime}$ \\
\hline Compost & $1.75 \mathrm{a}$ & $1.67 \mathrm{ab}$ & $1.71 \mathrm{~A}^{\prime}$ & $0.18 \mathrm{a}$ & $0.15 \mathrm{~d}$ & $0.16 \mathrm{~B}^{\prime}$ & $0.76 \mathrm{ab}$ & $0.68 \mathrm{a}-\mathrm{c}$ & $0.72 \mathrm{~A}^{\prime}$ \\
\hline Cattle manure & $1.38 \mathrm{bc}$ & $1.34 \mathrm{c}$ & $1.36 \mathrm{~B}^{\prime}$ & $0.17 \mathrm{c}$ & $0.17 \mathrm{c}$ & $0.17 \mathrm{~A}^{\prime}$ & $0.62 \mathrm{c}$ & $0.63 \mathrm{c}$ & '0.62B' \\
\hline Mineral 1 & $1.36 \mathrm{c}$ & $1.31 \mathrm{c}$ & $1.34 \mathrm{~B}^{\prime}$ & $0.17 \mathrm{c}$ & $0.17 \mathrm{c}$ & $0.17 \mathrm{~A}^{\prime}$ & $0.65 b c$ & $0.61 \mathrm{c}$ & $0.63 \mathrm{~B}^{\prime}$ \\
\hline Mineral 2 & $1.38 \mathrm{bc}$ & $1.36 \mathrm{bc}$ & $1.37 \mathrm{~B}^{\prime}$ & $0.17 \mathrm{c}$ & $0.18 \mathrm{~b}$ & $0.17 \mathrm{~A}^{\prime}$ & $0.62 \mathrm{c}$ & $0.61 \mathrm{c}$ & $0.61 \mathrm{~B}^{\prime}$ \\
\hline \multirow[t]{2}{*}{ Mean } & $1.54 \mathrm{~A}$ & $1.45 \mathrm{~A}$ & & $0.17 \mathrm{~A}$ & $0.16 \mathrm{~B}$ & & $0.68 \mathrm{~A}$ & $0.65 \mathrm{~A}$ & \\
\hline & \multicolumn{9}{|c|}{2017 season } \\
\hline Chicken manure & $1.71 \mathrm{a}$ & $1.62 \mathrm{ab}$ & $1.67 \mathrm{~A}^{\prime}$ & $0.18 \mathrm{ab}$ & $0.14 \mathrm{~b}$ & $0.16 \mathrm{~B}^{\prime}$ & $0.66 b$ & $0.73 \mathrm{a}$ & $0.70 \mathrm{~A}^{\prime}$ \\
\hline Compost & $1.67 \mathrm{a}$ & $1.58 \mathrm{ab}$ & $1.62 \mathrm{~A}^{\prime}$ & $0.20 \mathrm{ab}$ & $0.21 \mathrm{a}$ & $0.20 \mathrm{~A}^{\prime}$ & $0.71 \mathrm{ab}$ & $0.73 a$ & $0.72 \mathrm{~A}^{\prime}$ \\
\hline Cattle manure & $1.34 \mathrm{~b}$ & $1.40 \mathrm{ab}$ & $1.37 \mathrm{~B}^{\prime}$ & $0.17 \mathrm{ab}$ & $0.15 \mathrm{ab}$ & $0.16 \mathrm{~B}^{\prime}$ & $0.69 \mathrm{ab}$ & $0.69 \mathrm{ab}$ & $0.69 \mathrm{~A}^{\prime}$ \\
\hline Mineral 1 & $1.40 \mathrm{ab}$ & $1.52 \mathrm{ab}$ & $1.46 \mathrm{AB}^{\prime}$ & $0.19 \mathrm{ab}$ & $0.17 \mathrm{ab}$ & $0.18 \mathrm{AB}^{\prime}$ & $0.73 a$ & $0.73 a$ & $0.73 \mathrm{~A}^{\prime}$ \\
\hline Mineral 2 & $1.34 \mathrm{~b}$ & $1.45 \mathrm{ab}$ & $1.39 \mathrm{~B}^{\prime}$ & $0.19 \mathrm{ab}$ & $0.16 \mathrm{ab}$ & $0.18 \mathrm{AB}^{\prime}$ & $0.69 \mathrm{ab}$ & $0.71 \mathrm{ab}$ & $0.70 \mathrm{~A}^{\prime}$ \\
\hline Mean & $1.49 \mathrm{~A}$ & $1.52 \mathrm{~A}$ & & $0.18 \mathrm{~A}$ & $0.17 \mathrm{~B}$ & & $0.70 \mathrm{~A}$ & $0.72 \mathrm{~A}$ & \\
\hline
\end{tabular}

In each season, means of each of humic acid and nitrogen fertilizers sources or their interactions having the same letters are not significantly different at $5 \%$ level. 
TABLE 8. Effect of humic acid and some nitrogen fertilizers sources on Fe, $\mathrm{Zn}$ and Mn content in leaves of wonderful pomegranate trees during 2015,2016 and 2017 seasons.

\begin{tabular}{|c|c|c|c|c|c|c|c|c|c|}
\hline \multirow{3}{*}{$\begin{array}{l}\text { Nitrogen fertilizers } \\
\text { sources }\end{array}$} & \multicolumn{7}{|c|}{ Humic acid (50g/tree/year) } & \multirow[b]{2}{*}{ With } & \multirow[b]{2}{*}{ Mean } \\
\hline & Without & With & Mean & Without & With & Mean & Without & & \\
\hline & \multicolumn{3}{|c|}{ Fe (ppm) } & \multicolumn{3}{|c|}{ Zn (ppm) } & & \multicolumn{2}{|r|}{ Mn (ppm) } \\
\hline & \multicolumn{9}{|c|}{2015 season } \\
\hline Chicken manure & $126.8 \mathrm{bc}$ & $82.1 \mathrm{c}-\mathrm{e}$ & $104.5 \mathrm{~B}^{\prime}$ & $18.3 \mathrm{a}-\mathrm{d}$ & $17.9 \mathrm{a}-\mathrm{d}$ & $18.1 \mathrm{BC}^{\prime}$ & $49.1 \mathrm{a}$ & $47.4 \mathrm{a}$ & $48.3 \mathrm{~A}^{\prime}$ \\
\hline Compost & $134.6 \mathrm{ab}$ & $173.8 \mathrm{a}$ & $154.2 \mathrm{~A}^{\prime}$ & $26.4 \mathrm{a}$ & $25.6 \mathrm{a}$ & $26.0 \mathrm{~A}^{\prime}$ & $45.0 \mathrm{ab}$ & $48.6 \mathrm{a}$ & $46.8 \mathrm{~A}^{\prime}$ \\
\hline Cattle manure & $125.8 b c$ & $\begin{array}{l}112.0 \mathrm{~b}- \\
\mathrm{d}\end{array}$ & $118.9 \mathrm{~B}^{\prime}$ & $21.8 \mathrm{a}-\mathrm{c}$ & $25.2 \mathrm{ab}$ & $23.5 \mathrm{AB}^{\prime}$ & $42.3 b c$ & $39.3 \mathrm{c}-\mathrm{e}$ & $40.8 \mathrm{~B}^{\prime}$ \\
\hline Mineral 1 & $64.1 \mathrm{e}$ & $72.1 \mathrm{de}$ & $68.1 C^{\prime}$ & $15.7 \mathrm{~cd}$ & $13.9 \mathrm{~cd}$ & $14.8 C^{\prime}$ & $41.8 b-d$ & $35.7 \mathrm{e}$ & $38.8 \mathrm{~B}^{\prime}$ \\
\hline Mineral 2 & $63.0 \mathrm{e}$ & $69.7 \mathrm{de}$ & $66.4 C^{\prime}$ & $16.8 b-d$ & $12.9 \mathrm{~d}$ & $14.9 \mathrm{C}^{\prime}$ & $42.3 \mathrm{bc}$ & $37.7 \mathrm{~d}-\mathrm{e}$ & $40.0 \mathrm{~B}^{\prime}$ \\
\hline \multirow[t]{2}{*}{ Mean } & $102.9 \mathrm{~A}$ & $102.0 \mathrm{~A}$ & & $19.8 \mathrm{~A}$ & $19.1 \mathrm{~A}$ & & $44.1 \mathrm{~A}$ & 41.7B & \\
\hline & \multicolumn{9}{|c|}{2016 season } \\
\hline Chicken manure & $139.2 \mathrm{a}$ & $67.6 \mathrm{c}$ & $103.4 \mathrm{~A}^{\prime}$ & $15.5 b$ & $14.7 b$ & $15.1 \mathrm{AB}^{\prime}$ & $43.8 \mathrm{a}$ & $42.2 \mathrm{a}$ & $43.0 \mathrm{AB}^{\prime}$ \\
\hline Compost & $110.9 \mathrm{ab}$ & $97.8 b c$ & $104.4 \mathrm{~A}^{\prime}$ & $22.1 \mathrm{a}$ & $13.3 b$ & $17.7 \mathrm{~A}^{\prime}$ & $40.8 \mathrm{a}$ & $44.8 \mathrm{a}$ & $42.8 \mathrm{AB}^{\prime}$ \\
\hline Cattle manure & $84.2 \mathrm{bc}$ & $85.9 b c$ & $85.1 \mathrm{~A}^{\prime}$ & $13.6 \mathrm{~b}$ & $11.4 \mathrm{~b}$ & $12.5 \mathrm{~B}^{\prime}$ & $39.6 \mathrm{a}$ & $37.2 \mathrm{a}$ & $38.4 \mathrm{~B}^{\prime}$ \\
\hline Mineral 1 & $91.8 \mathrm{bc}$ & $88.5 b c$ & $90.2 \mathrm{~A}^{\prime}$ & $15.4 \mathrm{~b}$ & $14.6 \mathrm{~b}$ & $15.0 \mathrm{AB}^{\prime}$ & $46.9 \mathrm{a}$ & $47.0 \mathrm{a}$ & $47.0 \mathrm{~A}^{\prime}$ \\
\hline Mineral 2 & $88.8 \mathrm{bc}$ & $87.2 \mathrm{bc}$ & $88.0 \mathrm{~A}^{\prime}$ & $14.1 \mathrm{~b}$ & $12.8 \mathrm{~b}$ & $13.5 \mathrm{~B}^{\prime}$ & $45.6 \mathrm{a}$ & $45.0 \mathrm{a}$ & $45.3 \mathrm{AB}^{\prime}$ \\
\hline \multirow[t]{2}{*}{ Mean } & $103.0 \mathrm{~A}$ & $85.4 \mathrm{~B}$ & & $16.1 \mathrm{~A}$ & $13.4 \mathrm{~B}$ & & $43.4 \mathrm{~A}$ & $43.2 \mathrm{~A}$ & \\
\hline & \multicolumn{9}{|c|}{2017 season } \\
\hline Chicken manure & $78.5 \mathrm{bc}$ & $77.6 \mathrm{bc}$ & $78.1 \mathrm{~B}^{\prime}$ & $17.6 \mathrm{ab}$ & $24.7 \mathrm{a}$ & $21.2 \mathrm{~A}^{\prime}$ & $44.0 \mathrm{ab}$ & $42.4 \mathrm{ab}$ & $43.1 \mathrm{AB}^{\prime}$ \\
\hline Compost & $120.9 \mathrm{a}$ & $107.8 \mathrm{ab}$ & $114.4 \mathrm{~A}^{\prime}$ & $19.3 \mathrm{ab}$ & $19.0 \mathrm{ab}$ & $19.2 \mathrm{~A}^{\prime}$ & $42.8 \mathrm{ab}$ & $42.6 \mathrm{ab}$ & $42.7 \mathrm{AB}^{\prime}$ \\
\hline Cattle manure & $64.2 \mathrm{c}$ & $92.6 a-c$ & $78.4 \mathrm{~B}^{\prime}$ & $13.7 b$ & $16.3 \mathrm{ab}$ & $15.0 \mathrm{~A}^{\prime}$ & $41.4 \mathrm{ab}$ & $37.6 \mathrm{~b}$ & $39.5 \mathrm{~B}^{\prime}$ \\
\hline Mineral 1 & $71.7 \mathrm{bc}$ & $78.7 b c$ & $75.2 \mathrm{~B}^{\prime}$ & $17.5 \mathrm{ab}$ & $12.8 \mathrm{~b}$ & $15.2 \mathrm{~A}^{\prime}$ & $48.2 \mathrm{a}$ & $45.0 \mathrm{ab}$ & $46.6 \mathrm{~A}^{\prime}$ \\
\hline Mineral 2 & $68.8 b c$ & $77.2 \mathrm{bc}$ & $73.0 \mathrm{~B}^{\prime}$ & $16.6 \mathrm{ab}$ & $12.8 \mathrm{~b}$ & $14.7 A^{\prime}$ & $45.6 \mathrm{ab}$ & $38.7 b$ & $42.1 \mathrm{AB}^{\prime}$ \\
\hline Mean & $80.8 \mathrm{~A}$ & $86.8 \mathrm{~A}$ & & $17.0 \mathrm{~A}$ & $17.1 \mathrm{~A}$ & & $44.4 \mathrm{~A}$ & $41.3 \mathrm{~A}$ & \\
\hline
\end{tabular}

In each season, means of each of humic acid and nitrogen fertilizers sources or their interactions having the same letters are not significantly different at $5 \%$ level.

\section{Conclusion and Recommendation}

From the foregoing results, it could be concluded that under our experiment conditions, humic acid addition affected lack significant on yield, fruit physical and chemical properties and leaf nutrient content. This results are in line with those obtained by El-wakeel and Eid (2011) who reported that, highest stem thickness of three years old Navel orange trees budded on sour orange rootstock on clay loam soil increment percentage was recorded by mixed nitrogen form $(50 \%$ mineral $\mathrm{N}+50 \%$ organic $\mathrm{N})$ at 300 $\mathrm{g} /$ tree/year without $\mathrm{K}$ humate, leaf dry matter percentage gave higher significant value without $\mathrm{K}$ humate addition than that of with $\mathrm{K}$ humate, and also mixed nitrogen source at $300 \mathrm{~g} /$ tree/year without $\mathrm{K}$ humate recorded higher significant values of, leaf potassium content compared with some other treatments. In most cases, all nitrogen fertilizers increased yield, fruit physical and chemical properties when compared with cattle manure whereas, chicken manure and compost gave the highest values of most characters such Egypt. J. Hort. Vol. 45, No. 1 (2018) yield, arils weight, TSS and leaf mineral content followed closely by two mineral treatments. When compared between two mineral treatments it could be concluded that mineral 1 (40kg N/fed /year) was sufficient for gave the high values equaled by mineral $2(80 \mathrm{~kg} \mathrm{~N} / \mathrm{fed} /$ year $)$. That is according with (Eman et al., 2010) who concluded that, $50 \%$ of the fertilized Arabi pomegranate trees with recommended rate of NPK + humic acid $25 \mathrm{~g} /$ tree is the promising treatment. Moreover, it reduced half the amount of the recommended mineral fertilizers as well as soil pollution. Regarding the combination between humic acid and sources of nitrogen fertilizers the data showed that chicken manure and compost under any level of humic gave the highest values of yield and fruit characters followed closely by two mineral treatments under any level of humic.

Thus it could be safely recommended by

- For the conventional orchard of "Wonderful" cv. pomegranate fertilizing by $(40 \mathrm{~kg} \mathrm{~N} /$ 
fed /year) instead of ( $80 \mathrm{~kg} \mathrm{~N} /$ fed /year) was sufficient for yield, fruit quality and leaf mineral content and save cost.

- For the organic orchard of "Wonderful" cv. pomegranate fertilizing by chicken manure or compost (40kg N/fed /year) with or without humic addition (50 g/tree/year) improved yield, fruit physical and chemical properties and reduce environmental pollution.

- Therefore, "Wonderful" cv. pomegranate production in Egypt can depend on organic manure as an alternative to nitrogen mineral fertilizers, or at least save its use in the production of organic "Wonderful" cv. pomegranate as well as increasing in yield and fruit quality.

Concerning the above observation of the study, further researches are needed to verify the final recommendation. May be pomegranate growers need another study on some different mixtures of organic fertilizers and between organic and mineral fertilizers.

\section{Acknowledgments}

My sincere thanks and appreciation to the management of Hegazi Company for its strong support for conducting the research experiment in pomegranate orchards belonging to the company.

\section{Funding statements}

This research did not get any external funding.

\section{Conflicts of interest}

There are no conflicts of interest during this research.

\section{References}

Abd El-Rhman, I. E. (2017) Effect of Magnetic Iron and Potassium Humate on Growth, Yield and Fruit Quality of pomegranate Trees in Siwa Oasis, Egypt. International Journal of Environment, 6 (3), 103-113.

Abdelraheem, A., El-Wakeel, H., Abd El Hamid, A. and Noha Mansour (2015) Effect of Organic and Biological Nitrogen Fertilization on Growth, Yield, Fruit Quality and Nutritional status of Superior Grapevines. J. Biol. Chem. Environ. Sci., 10 (1), 481-503

Ali, O.T., Sayed, H. G., Babak, M., Mohammad, A.A.S. and Abdolkarim, Z. (2017) Effect of organic and biological fertilizers on pomegranate trees: yield, cracking, sunburning and infestation to pomegranate fruit moth Ectomyelois ceratoniae (Lepidoptera: Pyralidae). J. Crop Prot., 6 (3), 327-340.
Altieri, M.A. and Nicholls, C. I. (2003)Soil fertility management and insect pests: harmonizing soil and plant health in agroecosystems. Soil and Tillage Research, 72, 203-11.

A.O.A.C. (1995) "Official Method and Analysis of The Association oh The Official Analytical Chemists" $16^{\text {th }}$ ed. Washington DC,USA., pp. 490-510.

A.O.A.C. (1984) "Official Methods of Analysis of The Association oh The Official Analytical Chemists" $15^{\text {th }}$ ed. Washington DC, USA., pp 414 420 .

Barakat, M.R., Yehia, T.A. and Sayed, B.M. (2012) Response of Newhall Naval Orange to BioOrganic Fertilization under Newly Reclaimed Area Conditions I: Vegetative Growth and Nutritional Status. Journal of Horticultural Science \& Ornamental Plants, 4, (1), 18-25.

Cottenie, A.,Verloo,M.,Kiekens,L.,Velghe, G.and Camerlynck,R. (1982) "Chemical Analysis of Plants and Soils ", State Univ. Ghent, Belgium, 63, 44-45.

Duncan, D.B. (1955) Multiple range and multiple F tests. Biometrics, 11, 1- 42.

Duttaray, S.K., Takawale, P.V., Chatterjee, R. and Hnamte, V. (2014) Yield and quality of Pomegranate as influenced by organic and inorganic nutrients. The Bioscan, 9 (2), 617-620.

Eissa Fawzia, M., Faith, M.A. and El-Shall, S.A. (2007) The Role of humic acid and rootstock in enhancing salt tolerance of "Le-Conte" pear seedlings. $J$. Agric Sci. Mansoura Univ., 32, 3651-3666.

El Wakeel, H. and .Eid, M.A (2011) The Response of Nonbearing Navel Orange Trees for Mineral and Organic Nitrogen Fertilization Treatments and KHumate Addition. Journal of American Science, 7 (5), 121-141.

Eman E.K. Abd-Ella, Mervate, S.S. and Wafaa, A.Z. (2010) Effect of some organic and mineral fertilizer applications on growth and productivity of pomegranate trees. Alexandria Science Exchange Journal, 31 (3), 296 - 304.

Fathy, M.A., Gabr, M.A. and El Shall, S.A. (2010) Effect of humic acid treatments on 'Canino' apricot growth, yield and fruit quality. New York Sci. J., 3 (12), 109-115.

Fawzi, M., Shahin, F., Elham, A. and Kandil, E. (2010) Effect of organic and bio-fertilizers and magnesium sulphate on growth yield, chemical composition and fruit quality of "Le-Conte" Pear trees. Nature and Science, 8, 273-280.

Egypt. J. Hort. Vol. 45, No. 1 (2018) 
Fayed, T. (2005) Effect of some organic manures and biofertilizers on Anna apple trees. 2-Yield and fruit characteristics. Egyptian Journal of Applied Science, 20, 176-191.

Ismail, A.F., Hussien S.M., El- Shall S.A. and Fathi, M.A. (2007) Effect of irrigation and humic acid on Le-Conte pear. J. Agric. Sci., Mansoura Univ., 32, 7589-7603.

Jackson, M.L. (1973) "Soil Chemical Analysis", PrenticeHall of India Private Limited, New Delhi. 200 p.

Lansky, E.P. and Newman, R.A. (2007) Punica granatum (pomegranate) and its potential for prevention and treatment of inflammation and cancer. J. Ethnopharmacol., 109, 177-206.

Lowrison, G.C. (1993) “Fertilizer Technology", 2 nd ed. Ellis Limited, England. 543 p.

Magda, M. K., Shaban, A.E., El-Shrief, A.H. and ElDeen Mohamed, A. S. (2012) Effect of humic acid and amino acids on pomegranate trees under deficit irrigation. I: Growth, flowering and fruiting. Journal of Horticultural Science \& Ornamental Plants, 4 (3), 253-259.

Marzouk, H.A. and Kassem, H.A. (2011) Improving fruit quality, nutritional value and yield of Zaghloul dates by the application of organic and/or mineral fertilizers. Scientia Horticulturae, 127, 249-254.

Postagate, J. (1978) “Nitrogen Fixation”, $1^{\text {st }}$ ed. Edward Arnold, Inc. London p. 64.
Roy,S. and Waskar, D. (1997) Pomegranate. In postharvest physiology and storage of tropical and subtropical fruits, West Bengal, India, pp. 365-374

Shiralipour, A., McConnell, D. and Smith, W. (1992) Physical and chemical properties of soils as affected by municipal solid waste compost application. Biomass and Bioenergy, 3, 261-266.

Snedecor, G.W. and Cochran, W.G. (1972) "Statistical Methods", $6^{\text {th }}$ ed. Iowa State Univ. Press, Ames, Iowa, pp. 250-254.

Sudhakar, G., Cristopher, A.L., Rangaswamy, A. (2002). Effect of vermicompost application on the soil properties, nutrient availability, uptake and yield of rice-a review. Agric. Rev., 23 (2), 127-133.

Tan, K.H. (2003) "Humic Matter in Soil and Environment, Principles and Controversies", Marcel Dekker, Inc., Madison, New York, 408 p.

Wilde, S.A., Gorey, B.B., Layer, J.G. and Voigt, J.K (1985) "Soils and Plant Analysis for Tree Culture", published by Mohan primlani, Oxford and IBH publishing Co., New Delhi, pp. 1- 142.

(Received 10/04/2018 accepted 13/05/2018) 


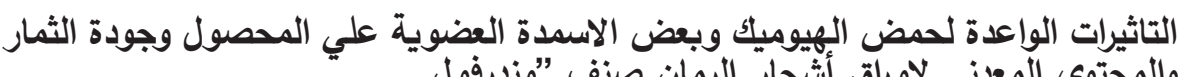
والمحتوى المعدنى لاورلق أثجار الرمان صنف "وندرفولئول

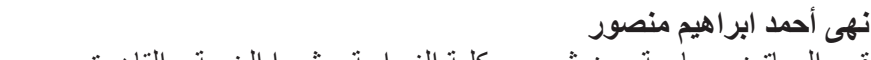

قسم البساتين - جامعة عين شمس ـ كلية الزر اعة ـ شبر ا الخيمة ـ القاهرة ـ مصر.

يهدف هذا البحث لاراسة أمكانية خفض استخدام الاسمدة المعدنية النتروجينية وتقييم استخدام بعض الاسمدة

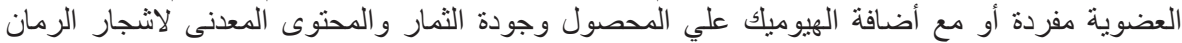

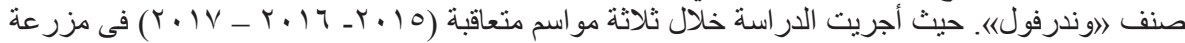

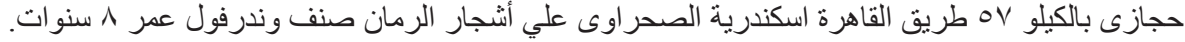

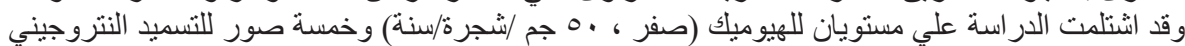

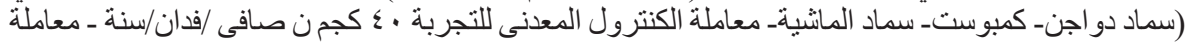

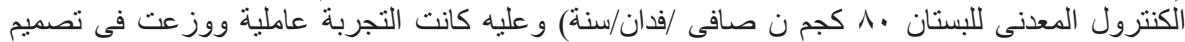

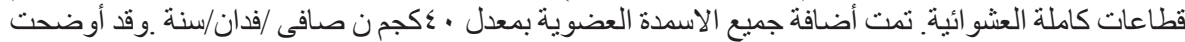

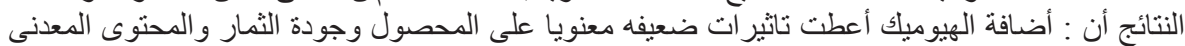

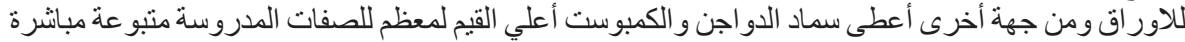

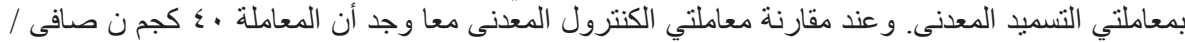

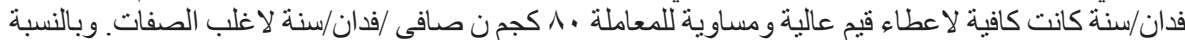

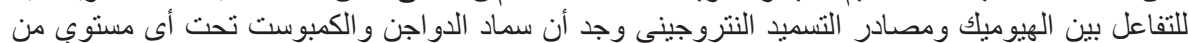

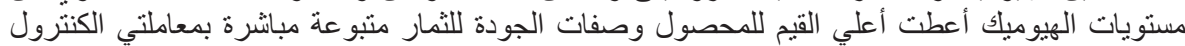

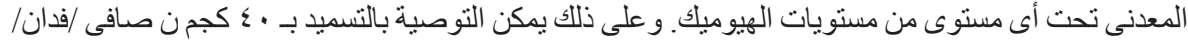

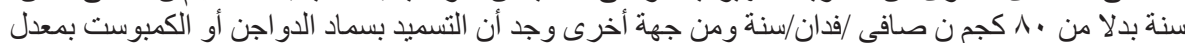

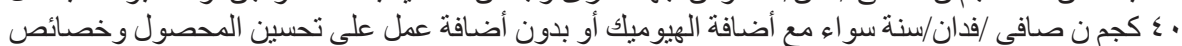
الجودة للثمار وتقليل التلوث البئئ. 